This item was submitted to Loughborough's Research Repository by the author.

Items in Figshare are protected by copyright, with all rights reserved, unless otherwise indicated.

\title{
'Value', 'cost' and ethics: UK airports and the governance of pandemic H1N1
} risk

PLEASE CITE THE PUBLISHED VERSION

VERSION

NA (Not Applicable or Unknown)

LICENCE

CC BY-NC-ND 4.0

\section{REPOSITORY RECORD}

Budd, Lucy C.S., Adam P. Warren, and Morag Bell. 2019. "'value', 'cost' and Ethics: UK Airports and the Governance of Pandemic H1N1 Risk". figshare. https://hdl.handle.net/2134/5833. 
This item was submitted to Loughborough's Institutional Repository (https://dspace.lboro.ac.uk/) by the author and is made available under the following Creative Commons Licence conditions.

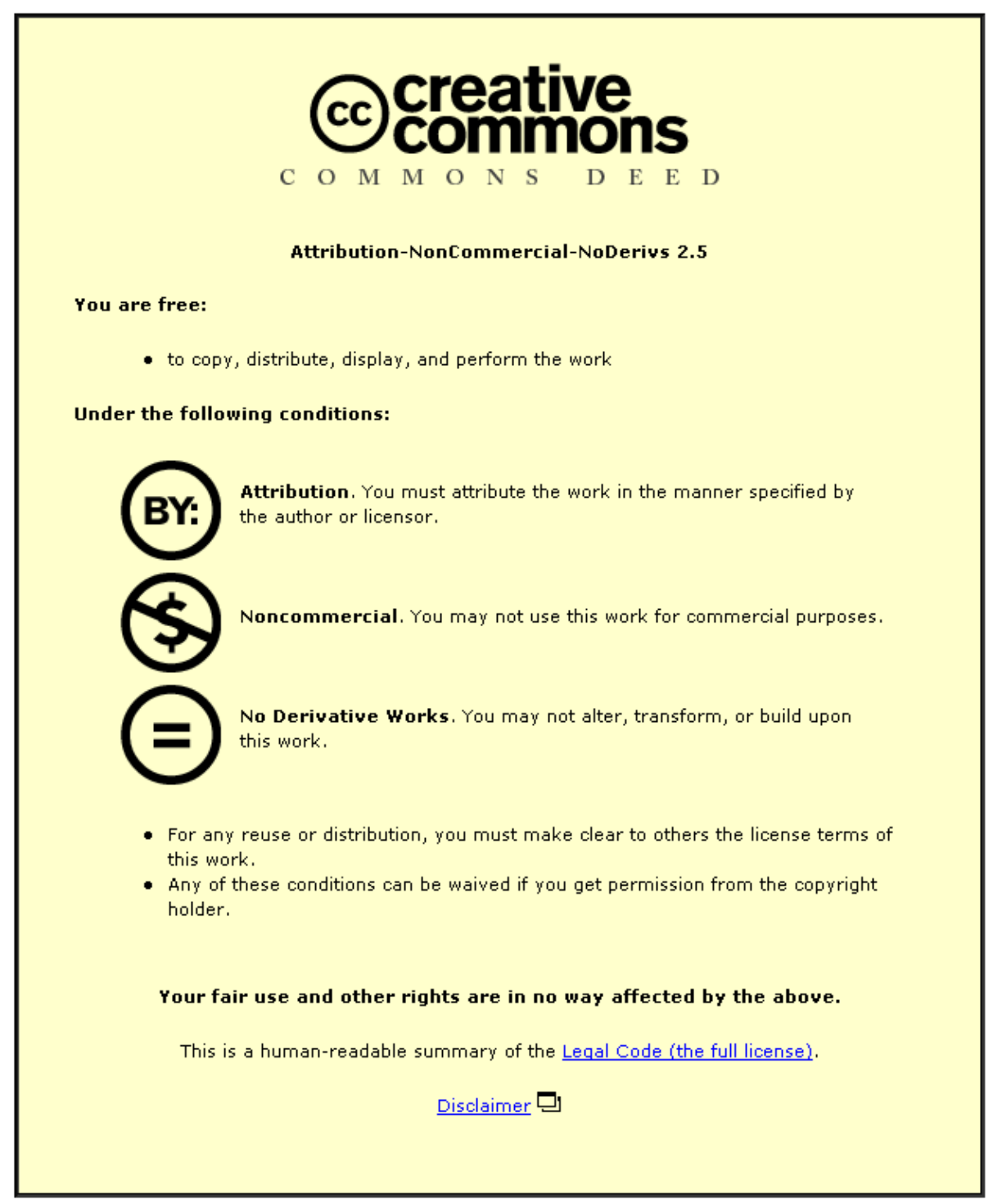

For the full text of this licence, please go to: http://creativecommons.org/licenses/by-nc-nd/2.5/ 
'Value', 'cost' and ethics: UK airports and the governance of pandemic H1N1 risk Lucy Budd*, Adam Warren**, and Morag Bell**

* Transport Studies Group, Department of Civil and Building Engineering, Loughborough University ** Geography Department, Loughborough University

\begin{abstract}
The outbreak and subsequent worldwide spread of pandemic influenza H1N1, popularly known as 'swine flu', from the spring of 2009 has illustrated our continued microbial vulnerability in a highly interconnected aeromobile world. The UK has been particularly affected by the first 'wave' of infection, with some commentators suggesting this was an inevitable consequence of the country's status as a hub of global air communications. Given that the virus was almost certainly brought to the UK by holidaymakers returning from Mexico, the role of the UK airport as the 'first line' of defence against the importation of infectious disease has been subject to particular scrutiny. An important debate has subsequently emerged surrounding the 'rights' of airline passengers to move unimpeded through the world's airports (without being subjected to medical screening) against the 'rights' of individual nations to be protected from the spread of infection through the employment of 'strict' screening practices. Focusing on concepts of 'value' and 'cost', as applied to individual 'forms of life', we consider how the governance of $\mathrm{H} 1 \mathrm{~N} 1$ risk at UK airports has generated a set of complex and interlocking biopolitical and ethical concerns associated with the safeguarding of the national border. We conclude by indicating how this tension, between securing and ethically valuing life, may inform future UK policy responses to infectious disease control at its international airports. One means is through a process of policy transfer.
\end{abstract}

\title{
Introduction
}

On March $18^{\text {th }} 2009$, health authorities in central Mexico were alerted to several incidents of flu-like illness among people living in and around the rural settlement of La Gloria, central Mexico. On April $12^{\text {th }}$, a 39-year old woman who was infected with what was later identified in a laboratory as the H1N1 strain of influenza, died of severe viral pneumonia in San Luis Potosi, central Mexico. Four days later, the Mexican Health Department notified the Pan American Health Organisation (PAHO), part of the World Health Organisation (WHO), of an outbreak of a new strain of 'swine' influenza. Reports began emerging of patients exhibiting similar symptoms in Mexico City and Mexicali, near the United States/Mexican border. On the $21^{\text {st }}$ April 2009, health authorities in the 
US confirmed that two children, a 10-year boy and a nine-year-old girl, living in adjacent counties, but $210 \mathrm{~km}$ apart, in California had tested positive for H1N1 infection. On April $22^{\text {nd }}$, the Mexican Health Ministry issued a nationwide alert after learning that 20 people across Mexico had died from a flu-like illness since the beginning of the year. Laboratory tests on Mexican samples confirmed that the viral strain was the same as that responsible for the Californian outbreak. By April $25^{\text {th }}$, the Mexican Health Authorities had provisionally attributed over 1300 cases and 81 deaths to the $\mathrm{H} 1 \mathrm{~N} 1$ virus while the US Centre for Disease Control (CDC) had reported 11 confirmed cases in three different States. By the beginning of May 2009, suspected cases of swine flu were being reported as far afield as Canada, the United Kingdom, Spain, Israel, and Australia. In the United Kingdom, a country that was subsequently particularly affected by the first 'wave' of infection, the Chief Medical Officer predicted that as many as 65,000 people could die as a result of contracting the virus and the National Health Service began a costly and controversial programme of vaccine procurement and administration (Laurance 2009; Gregory, 2009). Significantly, almost from the start of the outbreak, articles in the UK broadsheet press (the so-called 'quality' newspapers) discussed the role of aviation in the virus's worldwide spread and explained H1N1's rapid transmission as a consequence of infected airline passengers unwittingly transporting the virus around the world (Ayres et al, 2009; Hickman, 2009). Hence, from an early stage, the airport (and UK airports in particular) was identified as a site of particular risk.

In an effort to contain the spread of the virus, national health authorities around the globe, including those in the UK, were torn between a bio-political imperative to try to slow the virus's spread by introducing travel restrictions and/or new health screening procedures at airports without unduly hindering international travel and trade. As later sections of this paper show, some nations employed particular health security technologies, such as thermal imaging cameras, at their international airports to inspect the core body temperatures of all airline passengers arriving from infected areas, while others implemented rigorous quarantine and/or medical detention measures. As a result of these different ideological and practical approaches, an important debate emerged concerning the 'rights' of individual nations to be protected from the spread of infectious disease by air through their airports and the 'rights' of airline passengers to move unimpeded through the world's airports (without being subjected to intrusive medical screening).

\section{Structure and content of the paper}

The paper begins with a review of the existing literature on air travel, globalisation, and practices of global health security. It then examines the worldwide response to the H1N1 pandemic, focusing first on the health security protocols invoked at international airports overseas and then on the role UK passenger airports played as the 'first line' of defence against the spread of the infection. In order to examine the debate surrounding the 'rights' of individual nations to be protected from the spread of infection against the 'rights' of airline passengers to move unimpeded through the world's airports, we apply concepts of 'value' and 'cost' to individual 'forms of life' to consider how the 
governance of $\mathrm{H} 1 \mathrm{~N} 1$ risk at UK airports has generated a set of complex and interlocking biopolitical and ethical concerns associated with the safeguarding of the national border. We conclude by suggesting how this tension, between securing and ethically valuing life, may be designed into future UK policy responses to infectious disease control at its international airports. We contend that policy transfer may provide a theoretical framework to connect these perspectives in a way that may improve existing port health practices.

\section{Air travel and infectious disease}

Modern society is characterised by, and arguably largely dependent upon, the rapid and routine mobility of people and goods across vast distances. However, while globalisation has improved opportunities for travel and trade and enabled us to visit overseas countries and experience foreign cultures with relative ease, this interdependency is increasing the opportunities for the international spread of infectious diseases. Numerous medical and scientific studies have established clear relationships between the spatialities of the commercial aviation network and the global transmission of infectious disease (Royal and McCoubrey, 1989; Gerard, 2002; Mangili and Gendreau, 2005; Singer, 2005; Bowen and Laroe, 2006; Colizza et al, 2006; House of Lords, 2007), and recent research by Budd, Bell and Brown (2009) has shown how the development of sanitary regulations for civil aviation during the early-mid twentieth century continue to influence the contemporary governance of global public health in relation to air travel.

At the time of the last influenza pandemic, in 1968, 261 million passengers worldwide travelled by air (ICAO, 1968). In 2008, passenger air traffic exceeded two billion (ICAO, 2008). In line with international trends, air travel to and from the United Kingdom has grown rapidly over this period and this increased aeromobility has brought UK residents into contact with foreign infectious diseases for which they may have little or no natural immunity. According to UK Health Protection Agency (HPA) figures, in 2005 UK residents made 66.4 million trips abroad and 30 million international tourist arrivals were recorded (HPA, 2007). While the majority of this travel occurred between countries within the European Union, the number of visits to 'exotic' long-haul destinations in the Far East, Indian subcontinent, and South America has increased by nearly a third since 2003 (ibid. 2007). Such high volumes of international air travel exacerbate the challenges associated with disease containment. As the WHO observed with reference to air travel's role in the 2009 H1N1 outbreak:

'During previous pandemics, influenza viruses took $>6$ months to spread as widely as the new influenza A (H1N1) pandemic virus has taken to spread in <6 weeks... (WHO, 2009: 249).

While international efforts to control the spread of infectious disease date back to the use of quarantine in the fourteenth and fifteenth centuries, the development of regular long-haul air travel 
during the twentieth century necessitated the formation of new sanitary measures specifically targeted at aviation (see Budd et al, 2009). These regulations, which developed as a result of provisions contained within the First Sanitary Convention for Aerial Navigation of 1933, progressively defined new approaches for the identification and management of the threats posed by the 'classic' pestilential disease of cholera, smallpox, yellow fever, plague, and typhus to prevent their spread by air. Many of these approaches relied on interventions that were performed at or before the airport, including vaccination, disinsection (the eradiation of insects aboard aircraft using chemical insecticides), and disinfection. However, as the network of long-haul air routes, and the number of passengers using the new services, grew during the latter half of the twentieth century, safeguarding public health from the threat of infectious diseases being spread by air became increasingly challenging and a raft of new national and international legislation was introduced to try and counter new disease threats and cope with rising numbers of travellers.

Recent research by Wallis and Nerlich (2005) and Nerlich and Halliday (2007) has highlighted the difficulties often faced by national governments when trying to control the spread of infectious disease and Collier and Lakoff (2008) have 'problematized' the threat infectious diseases pose to a nation's health as 'biosecurity'. The concept of biosecurity - a broad title given to technical and political efforts to safeguard human and animal health - has become a prominent site of enquiry as researchers seek to understand various forms of expertise and practices through which disease threats are articulated and managed (Collier et al, 2004; Collier and Lakoff, 2008; Bingham et al, 2008). Two literatures are of particular relevance here. Firstly, emerging scholarly research focusing on the regulation of the international body in transit as it travels across the globe (Mangili and Gendreau, 2005; Tatem and Hay, 2007; Budd et al, 2009). Secondly, the work describing interventions employed by different nations on the ground to safeguard national biosecurity, particularly in response to new and emerging pathogenic threats (Collier and Lakoff, 2008; Fearnley, 2008; Nerlich et al, 2009).

Within these broad literatures, the international airport has been described as a site of command and control, where the movement of individual mobile bodies can be mapped and different identities can be ascribed (Salter, 2007; Adey, 2009; Budd et al, forthcoming). Much of this work has focused on anti-terrorist screening measures rather than disease (Adey, 2009; Amoore and Hall, 2009) and on the security practices employed by major airports overseas (Salter, 2007; Bennett, 2008). Nevertheless, we argue that the ascription of this role to UK airports has assumed greater importance during the last two decades, not least because the progressive liberalisation of the country's commercial aviation sector has multiplied the number of potential entry points through which 'exotic' diseases may enter its territory. This has had the effect of placing the border at the regions (Budd et al, forthcoming; Warren et al, forthcoming). 
Taken together, the extant literatures on commercial aviation, international disease regulation and biosecurity raise key questions about the regulation of the traveller's journey. They include the complexities involved in managing risk at various scales - international, national and regional - and the role assumed by the airport as a site of control. By examining risk and control in relation to the passenger journey during the early months of the H1N1 pandemic, we found that the concepts of 'value' and 'cost' assisted in our understanding of the dilemmas involved in safeguarding the health of the individual and the nation at UK airports.

\section{Managing risk at the airport - the varying international response to the H1N1 pandemic}

International responses to the spread of pandemic influenza H1N1 have varied. Some of the measures that were invoked, including compulsory quarantine, isolation, and medical detention, may be interpreted as rather more 'aggressive' than 'softer' techniques involving self-declaration health questionnaires and fever scanning. However, all of these practices demonstrated the complex role assumed by the airport in facilitating (human) mobility on the one hand and seeking to prevent the 'wrong' sort of human or disease mobility on the other. Typically, these measures involved the use of a health screening technology (particular thermal imaging cameras) and/or regulatory instruments that can result in the isolation and detention of individual travellers.

Table 1: Response to H1N1 outbreak by selected countries in Asia, April-May 2009.

\begin{tabular}{|l|l|}
\hline Country & Nature of response invoked at airports \\
\hline China & $\begin{array}{l}\text { Flights from USA sterilised. } \\
\text { Visitors required to complete health declaration cards. } \\
\text { Thermal scans of arriving passengers. }\end{array}$ \\
\hline Indonesia & Temperature scans installed at 10 airports. \\
\hline Japan & Thermal imaging cameras installed to screen arriving passengers. \\
\hline Philippines & $\begin{array}{l}\text { Temperature screening of all passengers from countries with reported H1N1 } \\
\text { cases. }\end{array}$ \\
\hline Singapore & Thermal screening of all passengers arriving from the USA. \\
\hline Thailand & Thermal scanning and maintenance of a database of foreign visitors. \\
\hline Vietnam & Thermal scans of passengers arriving from the USA, Canada, and Mexico. \\
\hline
\end{tabular}

Source: Data derived from Reuters UK (2009a, 2009b)

Mexico, the reported source of the pandemic outbreak, was one of the first nations to introduce health screening measures at its international airports. On $24^{\text {th }}$ April 2009, health inspectors began screening passengers at both Mexico City's Benito Juarez International Airport and at Toluca Airport, 37 miles $(60 \mathrm{~km})$ west of the capital, for symptoms of H1N1 infection. Medical screening procedures were also quickly implemented at other airports in Central and South America - 
including those in Argentina, Brazil, Chile, and Venezuela. Initially, these measures were targeted at arrivals from Mexico but later broadened to include travellers originating in other affected countries. In North America, the United States and Canada instructed medical inspection teams at major airports to be alert for travellers returning from Mexico who may be exhibiting symptoms of infection, while New Zealand and Australia increased their surveillance of passengers arriving from known $\mathrm{H} 1 \mathrm{~N} 1$ areas.

Elsewhere in the world, thermal imaging cameras were installed at major airports in Algeria, Bangladesh, China, Egypt, Indonesia, Oman, the Philippines, Saudi Arabia, Singapore, South Korea, Nepal, Sri Lanka, Thailand, and Vietnam, and targeted at travellers arriving from H1N1infected countries. Other countries, including India and Malaysia, employed thermal imaging scans in conjunction with health declaration cards, whilst health authorities in China ultimately introduced some of the strictest health security measures, including compulsory quarantine and the medical detention of travellers who were suspected of carrying the infection. This policy extended to the isolation and quarantine of entire planeloads of passengers. As of August 2009, it was reported that 56 million people had been screened for flu-like symptoms at the Chinese border (Wong, 2009).

\section{The governance of pandemic H1N1 risk at UK airports}

In the UK, the powers for applying health security measures on commercial aircraft and at airports are contained within the Public Health (Aircraft) Regulations Act 1979 and the Public Health (Control of Disease) Act 1984, as revised and updated in 2007. The new Public Health (Aircraft) (Amendment) (England) Regulations 2007 form one aspect of a package of legislative measures that are commonly referred to as the 'Port Health Regulations'. Similar legislation exists, or is planned, for the devolved administrations in Northern Ireland, Scotland, and Wales. The Port Health Regulations define the health security measures that can be invoked at UK airports against arriving and departing passengers, crew, and airfreight to limit any potential risks to public health and reduce the spread of infectious disease. These interventions include provisions for the medical examination of potential entrants to the UK, the grounding of aircraft and, if required, the detention of passengers, crew, air cargo, and equipment until local health authorities are satisfied that no disease threat exists (HPA, 2006a). The 1971 Immigration Act also empowers immigration officers at UK ports and airports to refer prospective entrants (who are subject to immigration control) for medical examination by a dedicated Port Medical Inspector (PMI). The Inspectors are appointed by the UK's Health Protection Agency (an independent organisation established in 2003 to protect public health in the UK), to defend the UK border from the importation of infectious disease. While an Immigration Officer can, in principle, refuse a potential applicant entry to the UK on public health grounds in light of a PMl's findings, there is little provision within the Port Health Regulations for actually applying health measures (other than offering certain vaccinations) to prospective entrants (HPA, 2006a). 
The main statutory responsibility for implementing the Port Health Regulations at the UK border at seaports, international railway stations, and airports rests with the local authority in which the transport facility is sited. Some local authorities in areas of heightened transportation activity are specifically designated as Port Health Authorities (PHAs). These PHAs were created in the second half of the nineteenth century to perform Port Health functions at entry points to the UK with the aim of preventing the international dissemination of dangerous communicable diseases, initially by ships, but now also by international rail and air services. The task of providing or commissioning specialist staff to implement the Port Health Regulations at (air/sea)ports in the UK rests with the Local Authority, the local Primary Care Trust (a division of the NHS in England that provides some primary and community health services), or the Health Protection Agency. The majority of staff employed by these institutions are either registered medical practitioners or certified environmental health officers.

As Budd et al (forthcoming) highlight, the relatively recent introduction of regular international air services to and from UK regional airports has meant that some local authorities in the UK (simply by virtue of having an airport located within their administrative boundaries) have had to quickly assume a Port Health function. Between 1948 and 2008, the number of UK airports handling international services increased from eight to 41 , with the majority of these new flights being introduced within the last decade (see DfT, 2005). This change to the spatial pattern of international air service provision was the result of a UK Government policy that sought to promote the growth of UK regional airports by liberalising the bilateral air service agreements that had previously regulated the routes that could be flown from each airport (DfT, 2003). As well as enabling existing UK carriers to launch new international routes, the UK Government also encouraged foreign airlines to begin operating new international services from regional airports (DfT, 2005). At the time of writing, Emirates of the UAE, Pakistan International Airlines, and Continental Airlines of the United States, among others, now operate regular long-haul international services to/from a number of UK regional airports including Birmingham, Newcastle and Glasgow. As a consequence of assuming this relatively new role as sites of long-haul international aeromobility, Budd et al (forthcoming) have suggested that the provisions for safeguarding public health at some regional airports may be less well defined than those at major London facilities which have had more experience at dealing with the public health challenges associated with regular long-haul air travel.

At present, much of the current Port Health surveillance strategy at UK airports is covert and relies on the visual inspection of departing and arriving passengers by check-in agents, cabin crew, and immigration officers, irrespective of the traveller's origin or destination. The procedural logic of airports means that there are only two channels - immigration and customs - through which all arriving passengers must pass. This obliges any point of entry health screening to be performed at one of these locations. At present, responsibility for identifying potentially infected/infectious 
travellers lies with individual immigration officers, who must assess both the originality and veracity of immigration documents and also whether each individual traveller poses a health security risk. Current protocols dictate that travellers not possessing an EU, North American, Australian, New Zealand or other 'Western' passport will be subject to more scrutiny (from both an immigration and an epidemiological perspective) than those that do. Moreover, continued UK government concern about the threat posed by tuberculosis means that chest radiography is the only medical screening technology that is routinely employed to safeguard public health at UK airports (HPA, 2006b).

The benefits of introducing additional screening technologies, particularly thermal imaging cameras, have been periodically debated in response to new and emerging disease threats. In response to the H1N1 influenza outbreak, some commentators called for the same technologies that are used at some airports overseas to be installed in the UK (see Warren et al, forthcoming). However, the potential introduction of any new screening technology invokes all manner of ethical, financial, technological and practical concerns. Their possible introduction has provoked considerable disagreement, with positions being polarised between those who feel that all possible measures should be taken to prevent the transmission of infectious disease and those who believe that some of the proposed new screening technologies go far beyond what is reasonable and infringe the privacy and dignity of individual travellers ${ }^{1}$.

\section{'Value', 'cost' and ethics: UK airports and the governance of pandemic H1N1 risk}

Recent empirical research conducted by the authors in the summer of 2009 indicated that there is a need to interrogate questions of 'value', 'cost' and ethics with respect to 'valuing human life' and health security measures at UK airports. 'Biosecurity' in its most literal sense refers securing life. But what forms of life are the regulatory authorities seeking to secure? And can, to paraphrase the question underpinning this workshop, forms of life be understood by analysing the 'value(s)' that individuals and populations (such as states and regions) seek to secure? In this paper, we have stated that our interest is in operations performed on the travelling body. Bingham and Hinchliffe argued that biosecurity could be best thought of as 'a specific problematization of conventional ways of dealing with living matters of concern' (2008: 190). Problematization - often associated with the work of Foucault (Dillon, 2007) - refers to the addressing of events or situations 'not as a given but as a question' (Collier and Lakoff, 2008: 11). Our recent work sought to question port health measures enacted at airports with a view to informing future practices. In this respect, we located 'value(s)' in terms of: freedom of individual movement; economic and societal 'cost'; and ethics.

\footnotetext{
${ }^{1}$ For debates on the motivations of screening for disease, refer: Coker and Ingram (2006) and Garoon and Duggan (2008).
} 
The attraction of air travel can be in a large part explained by the opportunities it affords for individual mobility across spaces. The airport has, in academic and popular literature alike, been portrayed in an optimistic light as 'spaces of flows' (Castells, 1996), frontiers that are not at the territorial limit, glamorous gateways to other places and grounded sites that encourage mobility (Salter, 2007, 2008). Although academic research is beginning to contest this somewhat naïve perspective, with scholars drawing particular attention to 'social sorting' and 'preemptive securitisation' of the travelling body (Lyon, 2007; Adey, 2009), there is reason to believe that international travellers may still view the airport as a site that affords personal freedom. Sheller (2008), in her exploration of mobility as a political freedom, highlighted the personal, sovereign and civic freedoms afforded by greater mobility. Some of these freedoms are rights-based. For example, Article 13 of the Universal Declaration on Human Rights recognises three types of freedom of movement: (i) the right to leave any country (including one's own); (ii) the right to return (to one's own country); and (iii) the right to freedom of movement within the borders of each state (UNDHR, 1948). Other freedoms are relational, and it is evident that the increase in cross-border personal mobility has benefitted selected categories of people such as 'mobile transnational professionals' (Nowicka, 2006 in Sheller 2008), tourists, business travellers and transnational migrants (Sheller, 2008: 27; Lyon, 2008). Nevertheless, existing 'postmodern' trends in airport design - with an emphasis on 'refashioning of nonplace' (Lloyd, 2003: 101) - have resulted in airports being rebranded as places of entertainment and 'pleasurable waiting' (Lloyd, 2003). This allows for a new kind of engagement between traveller and airport, with the latter being perceived as more site for the expression of consumerist 'value(s)' that define the freedoms of a marketdriven society rather than the restrictions of a surveillance society (Lloyd, 2003; Kesselring, 2008). Indeed, our study found little evidence that biosecurity practices had - at least in the instance of 'Western' travellers - obstructed passenger motilities or reduced levels of consumption.

Enabling these values (personal mobility and personal consumption) has nevertheless resulted in an economic 'cost'. Whilst adequate port health provision is a statutory requirement, it does not represent a valuable revenue stream for the airport. This is compounded by practical problems associated with providing effective port health safeguards. As a direct consequence of recent terrorist attacks against commercial aircraft and airports, all available space in the security search area has been devoted to anti-terrorist security measures meaning there is insufficient scope to provide port health professionals with any space in which to conduct routine passenger health screening. Likewise, on arrival, airport immigration and customs halls are designed to expedite the processing of potential entrants into the UK and intercept contraband good respectively. Consequently, very few sites have sufficient space to install entry-screening technologies. Notwithstanding this, there may be scope for introducing some sort of mobile screening technology that could be moved to different boarding gates as required to screen passengers as they disembark from 'high risk' flights. Arguably, the 'cost' incurred in providing port health facilities is dwarfed by the broader, societal, cost of inaction. Estimates of the impact of the H1N1 pandemic 
on the UK vary from a few million to $£ 50 \mathrm{bn}$, with a report in summer 2009 suggesting that the outbreak had set back UK economic recovery by several years (O'Grady, 2009). In this context, the 'rights' of individual aeromobile bodies to move unhindered through the world's airports may become subsumed under the 'rights' (or responsibilities) of individual countries to protect their citizens and residents from the spread of infectious disease.

Finally, 'valuing human life' is connected to a wider debate concerning ethics. Burgess, in his discussion of 'security as ethics', defines ethics as 'self-reflection':

'Ethics is the label for the recognition that we have choices, that we have opportunities. It is the insight that there are different ways of behaving' (2008: 4)

Collier and Lakoff discuss ethics in the context of 'biosecurity interventions' enacted by the WHO in response to the H5N1 influenza outbreak ${ }^{2}$, concluding that disputes surrounding these initiatives required:

'...new forms of political and ethical reasoning that take into account questions that are often only implicit in discussions of biosecurity interventions' (Collier and Lakoff, 2008, p, 28)

An analysis of UK press reporting of $\mathrm{H} 1 \mathrm{~N} 1$ pandemic influenza undertaken by the authors uncovered an emerging discourse on the 'ethical' long-haul traveller ${ }^{3}$. It took two forms. Firstly, in representations of the outward traveller - departing from the UK - as being responsible for securing his/her own personal health. This reporting - evident in large sections of the press - was in part a reaction to refers to the announcement by certain airlines and airports of intent to 'vet' passengers for possible H1N1 symptoms and request doctors' notes from those suspected of carrying the virus. On 19 July 2009, The Sunday Times was one among many newspapers to report that check-in staff at Heathrow and 'other main British airports' were 'vetting passengers' for possible H1N1 symptoms (19 July 2009. See also: Daily Telegraph, 20 July 2009; Daily Mail, 20 July 2009; The Guardian, 20 July 2009; The Times, 20 July 2009). These reports told of airlines' intention to 'turn away' passengers suspected of having $\mathrm{H} 1 \mathrm{~N} 1$ if they were unable to provide doctors' notes certifying they were 'fit to fly'. Although these practices were condemned on medical grounds by the BMA (The Times, 20 July 2009), they suggested an emerging presentation of the outward traveller as a threat to others, as someone who ought to reflect before making a decision to fly.

\footnotetext{
${ }^{2}$ For example, the authors refer to WHO protocols on the cull of domestic poultry in Cairo to safeguard against the spread of H5N1 - a measure that disproportionately affected the poor. (Refer also: Hinchliffe and Bingham, 2008).

3 This study was conducted during the period April - September 2009 - the reported 'first wave' of the outbreak. Refer: Warren et al (forthcoming).

${ }^{4}$ Reports named British Airways and Virgin Atlantic.
} 
This was supported by a second discourse advising the prospective traveller to consider the moral implications of his/her journey, particularly if the destination is one of the less developed countries of the global South. In a short article for The Observer, later referred to in a number of other national and regional publications ${ }^{5}$, Professor Robert Dingwall of Nottingham University drew attention to the potential for the UK traveller, especially gap year students working on developmental projects, to infect a population that may not be able to access antiviral medication and was more likely to suffer from severe underlying health conditions, such as tuberculosis (TB). Dingwall concluded that:

'While travel bans may not be justifiable, UK travellers cannot avoid thinking about their personal ethical responsibilities to the people of the countries that they are visiting. Staying at home this year will often be the morally right thing to do.' (The Observer, 2 August 2009)

Thus, in both representations, the outward traveller was being depicted as someone who ought to practice control over his/her body, managing the risk it posed to the less advantaged other. This perspective subverted much existing literature in this field, which had drawn on fearful evocations of the disease-carrying 'other' infecting the social body (Charteris-Black, 2006: 570; Cresswell, 2000; Kraut, 1995). It also contrasted with earlier UK national media discourse surrounding the 2001 TB outbreak in Leicester, which had been dominated by the need to control 'diseased' bodies wishing to enter the country (Bell et al, 2006).

\section{UK airports and the spread of disease: future policy responses}

These changed geographies of health security require new responses from the policy community. We argue that there is a need for more integrated biosecurity measures taking into account the infrastructures and resources of airports sited in the localities as well as in the global cities. Despite a large body of theoretical risk-based literature (for example, Amoore, 2006; Adey, 2009) and recent global outbreaks of infectious disease (SARS, H1N1), little attempt has been made to assess how health security is being enacted at individual airports in the UK and the extent to which existing practices may be improved. We suggest that one step towards achieving at least the latter may be through policy transfer:

'[a] process by which actors borrow policies developed in one setting to develop programmes and policies within another' (Dolowitz and Marsh, 1996: 357).

This process has been used to develop frameworks to advance earlier debates about the movement of ideas and practices in public and social policy (Ison, 2009). We believe that this existing work can provide a valuable theoretical framework to connect perspectives on health

\footnotetext{
${ }^{5}$ They include: Belfast Telegraph; Daily Mail; The Journal (Newcastle), Morning Star, South Wales Echo, The Western Mail, Yorkshire Post, Evening Chronicle (Newcastle)
} 
security. Ultimately, it could be used to inform the development of a decision support tool against which current UK airport practices can be measured and improved, taking into account policy work in other jurisdictions (Hulme, 2005).

\section{Conclusion}

The 2009 H1N1 influenza pandemic highlighted the UK's continued epidemiological vulnerability to infectious disease. Given that the virus was almost certainly brought to the UK by holidaymakers returning from Mexico, the role of the UK airport as the 'first line' of defence against the importation of infectious disease has been subject to particular scrutiny. This resulted in an important debate concerning the 'rights' of airline passengers to move unimpeded through the world's airports and the 'rights' of individual nations to be protected from the spread of infection through the employment of 'strict' screening practices. Focusing on concepts of 'value' and 'cost', as applied to individual 'forms of life', the paper considered how the governance of H1N1 risk at UK airports has generated a set of complex and interlocking biopolitical and ethical concerns associated with the safeguarding of the national border. Finally, we suggest that acknowledging this tension, between securing and ethically valuing life, could help inform future policy responses to the control of infectious diseases at UK airports.

\section{References}

Adey, P. (2009). Facing airport security: affect, biopolitics, and the preemptive securitisation of the mobile body, Environment and Planning D: Society and Space, 27: 274-295

Amoore L (2006) Biometric Borders: Governing mobilities in the war on terror. Political Geography 25 pp336-351

Amoore, L. and Hall, A. (2009). Taking people apart: digitised dissection and the body at the border, Environment and Planning D: Society and Space, 27: 444-464.

Ayres, C., Baldwin, T., and Lewis, L (2009). World on flu alert as travellers carry threat around the globe. The Times 27/04/2009: 6-7

Bell, M., Brown, T. and Faire, L. (2006). Germs, genes and postcolonial geographies: reading the return of tuberculosis to Leicester, UK, 2001 Cultural Geographies 13(4): 577-599.

Bennett, C.J. (2008) Unsafe at any altitude: the comparative politics of no-fly lists in the United States and Canada, Salter, M.B. (ed) Politics at the Airport, University of Minnesota Press, Minneapolis, 51-76

Bingham, N., Enticott, G., and Hinchcliffe, S. (2008). Biosecurity: spaces, practices, and boundaries Environment and Planning A 40(7); 1528-1533.

Bingham, N. and Hinchliffe, S. (2008) Mapping the multiplicities of biosecurity in Lakoff, A. and Collier, S.J. Biosecurity Interventions, New York: Columbia University Press, 173 - 193.

Bowen, J, T. and Laroe, C. (2006). Airline networks and the international diffusion of severe acute respiratory syndrome (SARS). The Geographical Journal 172(2): 130-144 
Budd, L, Bell, M., and Brown, T. (2009). Of plagues, planes and politics: controlling the global spread of infectious diseases by air Political Geography 28: 426-435

Budd, L., Warren, A. and Bell, M. (forthcoming). Global Health Governance in the UK: airport regulation and the mobile body Submitted to Transactions of the Institute of British Geographers

Burgess, J.P. (2008). Security as ethics Policy Brief No. 6/2008, Oslo, PRIO

Castells M (1996) The Rise of the Network Society: The Information Age: Economy, Society, and Culture Volume 1 Oxford, Blackwell.

Charteris-Black, J. (2006). Britain as a container: immigration metaphors in the 2005 election campaign. Discourse \& Society 17 (5) pp. 563-558.

Coker, R. and Ingram, A. (2006). Passports and Pestilence: Migration, Security and Contemporary Border Control of Infectious Diseases in Bashford, A. (Ed.) Medicine and the Border: Disease, Globalization, and Security, 1850 to present. London, Palgrave Macmillan.

Colizza, V., Barrat, A., Barthelemy, M. and Vespignani, A. (2006). The role of the airline transportation network in the prediction and predictability of global epidemics Proceedings of the National Academy of Sciences 103: 2015-2020.

Collier, S., Lakoff, A. and Rabinow, P. (2004) Biosecurity: towards an anthropology of the contemporary, Anthropology Today, 20 (5), 3-7

Collier, S.J. and Lakoff, A. (2008) The problem of securing health, in Lakoff, A. and Collier, S.J. Biosecurity Interventions, New York: Columbia University Press, 7 - 32.

Cresswell, T. (2000) 'Mobility, syphilis, and democracy: pathologizing the mobile body', in Revill, G. and Wrigley, R. (eds), Pathologies of travel (Amsterdam, Cliomedica/Wellcome Series in the History of Medicine, 2000), 261-77

Department for Transport (DfT). (2003). Future of Air Transport White Paper December London, HMSO.

DfT. (2005). Relaxation of restrictions on international services from UK regional airports Press release, $17^{\text {th }}$ October 2005. Retrieved from www.dft.gov.uk on 12/05/2006.

Dillon M, 2007, "Governing terror: the state of emergency of biopolitical emergence" International Political Sociology $17-28$

Dolowitz, D. P. and Marsh, D. (1996). Who learns what from whom: a review of the policy transfer literature Political Studies 44(2): 343-357.

Fearnley L, 2008, "Signals come and go: syndromic surveillance and styles of biosecurity" Environment and Planning A 401615 - 1632

Garoon, J. P., and Druggan, P. S. (2008). Discourses of disease, discourses of disadvantage: A critical analysis of National Pandemic Influenza Preparedness Plans Social Science and Medicine 67(7): 1133-1142.

Gerard, E. (2002). Infectious disease in air travellers arriving in the UK. Journal of the Royal Society of the Promotion of Health 122(2): 86-88.

Gregory, N. (2009). Catch it! Bin it! Profit from it! The Observer Magazine 25/10/09: 24-33 
Health Protection Agency (HPA). (2006a). Health Activity Relating to People at Ports, Airports, and international train stations in England London, HPA.

HPA (2006b) Port Health and Medical Inspection Review London, HPA.

HPA (2007). Foreign-travel associated illness England, Wales and Northern Ireland - 2007 Report London, Health Protection Agency.

Hickman, M. (2009). Swine flu sweeps the globe The Independent 27/04/09: 1.

House of Lords. (2007). Air Travel and Health: an Update. House of Lords Science and

Technology Committee. HL Paper 7. London, HMSO.

Hulme, R. (2005). Policy Transfer and the Internationalisation of Social Policy Social Policy and Society 4: 417-425

International Civil Aviation Organization (ICAO). (1968). Statistics Section. News Release. Growth in civil aviation.

ICAO. (2008). Annual Report of the Council, Doc 9916, ICAO, Montreal.

Ison, S. G. (2009). Policy transfer. Unpublished departmental working paper, Loughborough University.

Kesselring, S. (2008). Global transfer points: the making of airports in the mobile risk society in Cwerner, Kesselring and Urry (Eds.) (2008) Aeromobilities London, Routledge pp39-60.

Kraut, A. M. (1995). Silent Travelers: Germs, Genes and the Immigrant Menace, The Johns Hopkins University Press, Baltimore.

Laurance, J. (2009). NHS prepares for 65,000 deaths from swine flu The Independent 17/07/09 pp4-5.

Lloyd, J. (2003). Dwelltime Airport Technology, Travel and Consumption Space and culture 6(2): 93-109.

Lyon, D. (2007). Surveillance, Security and Social Sorting: Emerging Research Priorities International Criminal Justice Review 17 (3) :161-170

Lyon, D. (2008). Filtering flows, friends and foes: Global Surveillance. In Salter, M. B. (Ed). Politics at the Airport Minneapolis, University of Minnesota Press: 29-50.

Mangili, A. and Gendreau, M, A. (2005). Transmission of infectious diseases during commercial air travel. The Lancet 365(12): 989-996.

Nerlich,B., Brown, B. and Wright, N. (2009). The Ins and Outs of Biosecurity: Bird 'flu in East Anglia and the Spatial Representation of Risk Sociologia Ruralis: 1-16

Nerlich, B. and Halliday, C. (2007) Avian flu: the creation of expectations in the interplay between science and the media, Sociology of Health and IIIness, 29, 1: 46-65

O'Grady, S. (2009). Swine flu epidemic could derail Britain's recovery The Independent 20/07/2009: 35.

Reuters UK. (2009a). Asia moves to ward off new virus 27/04/2009 Retrieved from http://uk.reuters.com/article/IDUKSP393424 Last accessed 12/12/09.

Reuters UK. (2009b). Asia puts up fight as H1N1 makes inroads 21/05/2009 Retrieved from http://uk.reuters.com/article/idUKSP53722 Last accessed on 12/12/2009. 
Royal, L. and McCoubrey, I. (1989). International spread of disease by air travel. American Family Physician 40(5): 129-136.

Salter, M. B. (2007) Governmentalities of an airport: heterotopia and confession, International Political Sociology, 1, 49-66.

Salter, M. B. (2008) The global airport, in Salter, M.B. (ed) Politics at the Airport, University of Minnesota Press, Minneapolis, 1-28.

Sheller, M. (2008) Mobility, Freedom and Public Space in Bergmann, S. and Sager, T. (Eds.) The ethics of mobilities: rethinking place, exclusion, freedom and environment Aldershot, Ashgate: 25-64.

Singer, D, A. (2005). Transmission of infections during commercial air travel The Lancet 365: 2176-2177.

Tatem, A. J. and Hay, S. I. (2007). Climatic similarity and biological exchange in the worldwide airline transportation network Proceedings of the Royal Society B: Biological Sciences 274 (1617): 1489-1496.

UNDHR. (1948). Universal Declaration Human Rights Retrieved from http://www.un.org/en/documents/udhr/ on 12/12/2009.

Wallis, P and Nerlich, B (2005) Disease metaphors in new epidemics: the UK media framing of the 2003 SARS epidemic, Social Science and Medicine, 60, 2629-2639.

Warren, A. Bell, M. and Budd, L. (forthcoming) Airports, localities and disease: global travel as a threat to the UK regions. Health and Place.

Wong, E. (2009). China's tough policy seems to slow flu's spread The New York Times with The Observer 22/11/09: 7.

World Health Organisation (WHO). (2009). Influenza A(H1N1): lesson learned and preparedness, Dr Margaret Chan. Director-General of the World Health Organisation 2 July. 